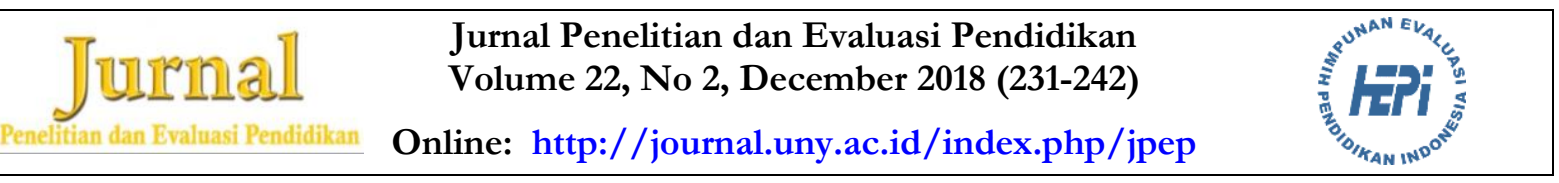

\title{
PENGEMBANGAN INSTRUMEN PENILAIAN AFEKTIF SISWA KELAS IV SEKOLAH DASAR DI KABUPATEN KLATEN
}

\author{
Anggarwati Riscaputantri ${ }^{1}$ *, Sri Wening 1 \\ ${ }^{1}$ Universitas Negeri Yogyakarta \\ 1J1. Colombo No. 1, Depok, Sleman 55281, Yogyakarta, Indonesia \\ * Corresponding Author. Email: anggarwati.riscaputantri2015@student.uny.ac.id
}

\begin{abstract}
Abstrak
Penelitian ini bertujuan untuk menghasilkan instrumen yang memenuhi syarat untuk mengukur afektif siswa kelas IV, dan mengetahui gambaran afektif siswa kelas IV tahun ajaran 2016/2017 di Kabupaten Klaten. Pendekatan yang digunakan dalam penelitian ini adalah Research and Development dengan Model Thiagarajan. Instrumen penilaian afektif telah dinyatakan valid dan reliabel. Validitas isi diuji oleh ahli dan diperoleh indeks Aiken sebesar 0,85. Validitas konstruk dilakukan dengan analisis faktor eksploratori dan konfirmatori. Hasil analisis faktor eksploratori menunjukkan nilai KMO sebesar 0,726 sedangkan Bartlett's Test sebesar Sig. 0,000. Hasil analisis faktor konfirmatori menunjukkan nilai Chi-Kuadrat sebesar 0,039; RMSEA $=0,012$; GFI $=0,93$; SRMR $=0,033$; AGFI=0,90; CFI=1,00; RFI=1,00. Hasil reliabilitas menunjukkan bahwa koefisien Cronbach's Alpha sebesar 0,653 sedangkan pada reliabilitas konstruk menunjukkan bahwa pada sikap disiplin koefisien $\mathrm{CR}=0,99$ dan $\mathrm{VE}=0,99$; sikap jujur $\mathrm{CR}=0,99$ dan $\mathrm{VE}=0,99$; sikap peduli $\mathrm{CR}=0,99$ dan $\mathrm{VE}=0,99$; sikap percaya diri $\mathrm{CR}=0,94$ dan $\mathrm{VE}=0,95$; sikap santun $\mathrm{CR}=0,99$ dan $\mathrm{VE}=0,81$; sikap tanggung jawab $\mathrm{CR}=0,99$ dan $\mathrm{VE}=0,79$. Gambaran afektif siswa adalah (a) berdasarkan tingkatan afektif Krathwohl, Bloom \& Masia pada tingkatan karakterisasi sebesar 42,9\%, mengorganisasi sebesar 50,9\%, menilai 6,2\% sedangkan tahapan merepon dan menerima sebesar $0 \%$, (b) berdasarkan acuan Kurikulum 2013 pada kategori baik sekali sebesar 62\%, kategori baik 38\% dan kategori cukup 1\%, kategori butuh bimbingan sebesar $0 \%$.
\end{abstract}

Kata kunci: penilaian afektif, sikap, tingkatan afektif Krathwobl, Bloom \& Masia, analisis faktor eksploratori, analisis faktor konfirmatori

\section{DEVELOPING AFFECTIVE ASSESMENT INSTRUMEN OF FOURTH GRADE STUDENT IN KLATEN REGENCY}

\begin{abstract}
This study aimed to: produce qualified instrument to measure an affective of grade IV students and find out the affective picture of fourth grade students in academic year 2016/2017 Klaten. This study used Research and Development approach by using Thiagarajan Model. Affective assessment instruments were stated as valid and reliable. Content validity was judged by experts. The Aiken index of instruments is 0.85 . Construct validity was measured by using both exploratory and confirmatory factor analysis. The results of exploratory factor analysis showed that the KMO value is 0.726 while the Bartlett's Test is equal to Sig. 0,000. Confirmatory factor analysis showed that ChiSquare value is 0.039; $\mathrm{RMSEA}=0.012$; GFI $=0.93$; $\mathrm{SRMR}=0.033$; $\mathrm{AGFI}=0.90 ; \mathrm{CFI}=1.00$; RFI $=1.00$. Cronbach's Alpha coefficient is 0.653 while the construct reliability showed the coefficient of discipline $\mathrm{CR}=0.99$ and $\mathrm{VE}=0.99$; honest attitude $\mathrm{CR}=0.99$ and $\mathrm{VE}=0.99$; attitude caring about $\mathrm{CR}=0.99$ and $\mathrm{VE}=0.99$; self-confidence $\mathrm{CR}=0.94$ and $\mathrm{VE}=0.95$; polite attitude $\mathrm{CR}=$ 0.99 and $\mathrm{VE}=0.81$; the attitude of responsibility $\mathrm{CR}=0.99$ and $\mathrm{VE}=0.79$. The description of students' affective was (a) based on the affective level of Krathwohl, Bloom \& Masia, level of characterization $42.9 \%$, organizing $50.9 \%$, assessing $6.2 \%$ while phoning and receiving $0 \%$, (b) based on the 2013 Curriculum reference, it could be stated as excellent category $62 \%$, favorable category $38 \%$ and fair category $1 \%$, the category needs guidance at $0 \%$.
\end{abstract}

Keywords: affective assessment, attitude, Krathwobl affective level, Bloom \& Masia, exploratory factor analysis, confirmatory factor analysis

Permalink/DOI: bttp:/ / dx.doi.org/10.21831/pep.v22i2.16885

Jurnal Penelitian dan Evaluasi Pendidikan

ISSN 2338-6061 (online) 


\section{Pendahuluan}

Sekolah dasar merupakan salah satu jenjang dalam pendidikan yang harus ditempuh oleh siswa. Berbagai visi dan misi disusun untuk mencapai tujuan dalam mendidik siswa. Salah satu visi yang saat ini diterapkan dan menjadi pupuler adalah membentuk karakter siswa. Hal tersebut bukan tanpa dasar namun merupakan wujud dari pelaksanaan Peraturan Menteri Pendidikan dan Kebudayaan Republik Indonesia Nomor 23 Tahun 2015 tentang Budi Pekerti (Menteri Pendidikan dan Kebudayaan Republik Indonesia, 2015) yang menyatakan bahwa pendidikan karakter seharusnya menjadi gerakan bersama melibatkan pemerintah, pemerintah daerah, masyarakat, dan atau orang tua. Berlandaskan hal tersebut, sekolah merupakan bagian dari pemerintah yang berupaya melaksanakan peraturan sebagai bentuk peran aktif membangun sumber daya manusia yang lebih baik melalui pendidikan.

Pendidikan karakter menurut Samani \& Hariyanto (2012, p. 45) menjelaskan bahwa pendidikan karakter merupakan proses pemberian tuntunan kepada siswa untuk menjadi manusia seutuhnya yang berkarakter dalam dimensi hati, pikir, raga serta karsa. Hal ini merujuk pada kesimpulan bahwa siswa yang hidup di lingkungan sosial dapat mempengaruhi pembentukan karakternya. Sekolah sebagai salah satu lingkungan yang membetuk karakter siswa diharapkan mampu memberikan perlakuan yang baik sehingga terbentuk karakter yang baik pula. Siswa pada jenjang sekolah dasar termasuk dalam tahapan operasional konkret. Hal ini menunjukkan bahwa siswa perlu dilibatkan secara langsung dalam kegiatan-kegiatan di sekolah maupun proses pembelajaran terkait penanaman karakter secara maksimal untuk membentuk karakter siswa. Selain itu, pendidikan yang berbasis karakter perlu memperhatikan proses pembelajaran terkait dengan ketercapaian pendidikan karakter tersebut.

Pembelajaran yang memuat nilai-nilai karakter akan menghasilkan siswa yang memiliki karakter yang diharapkan sesuai dengan tujuan pembelajaran. Hal tersebut didukung penelitian yang dilakukan oleh
Wening (2012, p. 1) menjelaskan dalam hasil penelitiannya bahwa pembentukan karakter siswa yang diberi intervensi pembelajaran nilai menggunakan buku cerita memberikan efek yang bermakna pada aspek pembentukan karakter siswa. Hal senada juga disampaikan oleh Adibatin (2016, p. 1) dalam penelitiannya menjelaskan bahwa hasil pembelajaran menggunakan alat peraga inovatif ini menunjukkan bahwa melalui strategi pembelajaran PAKEM dengan bermain cincin akik di jempol tangan dapat membangun karakter siswa sampai $11,33 \%$. Berdasarkan penelitianpenelitian yang telah dilakukan maka dapat disimpulkan bahwa pembelajaran disekolah memiliki peran dalam membentuk karakter siswa. Hal tersebut sesuai dengan tujuan sekolah yang disampaikan Mardapi (2012, p. 2) bahwa sekolah sebagai lemabaga pendidikan adalah mengembangkan potensi peserta didik secara optimal menjadi kemampuan untuk hidup dimasyarakat.

Pengembangan potensi peserta didik dapat dilakukan melalui proses belajar mengajar disekolah atau pengajaran. Pada proses pengajaran diharapkan adanya interaksi yang baik dari siswa dengan sumber belajar. Sumber belajar ini tidak hanya guru saja namun dapat diartikan sebagai media yang dapat memberikan sumbangan terhadap capaian belajar yaitu buku, alat peraga maupun media-media lain yang mendukung. Pencapaian hasil belajar sering disebut dengan hasil belajar merupakan tingkat kompetensi yang dicapai peserta didik yang mencakup tiga ranah, yaitu ranah kognitif, ranah afektif, dan ranah psikomotor (Mardapi, 2012, p. 2). Hal tersebut juga didukung oleh pendapat Krathwohl, Bloom, \& Masia (1973, p. 6) menjelaskan bahwa dalam pendidikan terdapat tiga domain atau ranah yang perlu diperhatikan yaitu ranah kognitif, afektif, dan psikomotorik. Pada ketiga domain atau ranah tersebut perlu diperhatikan karakteristiknya serta tidak ada yang lebih dominan, artinya guru sebagai fasilitator dalam proses pembelajaran perlu mempersiapkan capaian pembelajaran pada ketiga ranah tersebut, yaitu kognitif, afektif, dan psikomotorik. Menurut Haryadi \& Aripin (2015, p. 41) kog- 
nitif merupakan suatu pokok bahasan yang berhubungan dengan kognisi, dengan tujuan akhir berupa pengetahuan yang didapat melalui percobaan, penellitian, peneluan, dan pengamatan. Kognitif berhubungan erat dengan pikiran, memori, nalar, intelektual, kemampuan berhitung, logika, eksakta, sains, numerik dan akademik. Ranah psikomotor berhubungan dengan hasil belajar yang pencapaiannya melalui keterampilan manipulasi yang melibatkan otot dan kekuatan fisik. Mata pelajaran yang berkaitan dengan psikomotor adalah mata pelajaran yang lebih berorientasi pada gerakan dan menekankan pada reaksi-reaksi fisik dan keterampilan tangan. Tujuan pengukuran ranah psikomotor adalah selain untuk memperbaiki pencapaian tujuan instruksional oleh siswa pada ranah psikomotor khususnya pada tingkat imitasi, manipulasi presisi, artikulasi, dan naturalisasi, juga dapat meningkatkan kemampuan gerak reflex, gerak dasar, keterampilan perseptual, keterampilan fisik, gerak terampil, dan komunikasi non-diskusif siswa. Ranah ketiga yaitu afektif. Haryadi \& Aripin (2015, p. 41) menjelaskan bahwa afektif memiliki cakupan yang berbeda denga kognitif, afektif lebih berhubungan dengan psikis, jiwa dan rasa. Dijelaskan lebih lanjut bahwa pada afektif meliputi sikap yang ditunjukkan. Afektif juga dapat di artikan sebagai proses yang menekankan nada perasaan, emosi, atau tingkat penerimaan atau penolakan. Tujuan afektif bervariasi dari perhatian sederhana pada pehnomena terpilih hingga kualitas karakter dan hati nurani yang kompleks namun konsisten secara internal (Krathwohl et al., 1973, p. 7).

Salah satu penelitian yang dilakukan oleh Setyawan \& Dimyati (2015, p. 1) menjelaskan bahwa dalam menyusun proses pembelajaran yang berupa model permainan aktivitas luar kelas perlu memperhatikan capaian pembelajaran pada tiga ranah yaitu kognitif, afektif dan psikomotorik dengan hasil penelitian menunjukkan bahwa model permainan juga efektif untuk mengembangkan ranah kognitif, afektif, dan psikomotorik, yang dibuktikan dengan terjadinya pening- katan persentase nilai rata-rata siswa sebesar $21 \%$.

Keterkaitan pelaksanaan pembelajaran yang memiliki capaian pada tiga ranah kognitif, afekif dan psikomotorik tidak terlepas dari penilaian yang wajib dilakukan oleh guru setelah dilakukan proses belajar. Menyelenggarakan penilaian dan evaluasi proses dan hasil belajar merupakan kompetensi pedagogik yang harus dilaksanakan guru. Penilaian menurut Peraturan Menteri Pendidikan dan Kebudayaa Repubik Indonesia Nomor 23 Tahun 2016 tentang Standar Penilaian (Menteri Pendidikan dan Kebudayaan Republik Indonesia, 2016) pada pasal 1 menjelaskan bahwa penilaian adalah proses pengumpulan dan pengolahan informasi untuk mengukur pencapaian hasil belajar peserta didik. Hasil belajar siswa merupakan informasi bagi guru untuk melihat keberhasilan belajar siswanya. Pentingnya hasil belajar tersebut, maka guru memerlukan alat untuk mengumpulkan informasi berupa data. Alat yang digunakan untuk mengumpulkan data tersebut disebut instrumen penilaian hasil belajar.

Instrumen penilaian hasil belajar dikelompokkan menjadi dua yaitu tes dan nontes. Penilaian tes dilakukan untuk menguji kemampuan kognitif siswa. Pada kemampuan afektif dan psikomotorik siswa dapat menggunakan bentuk penilaian non-tes. Guru perlu melakukan penilaian pada ketiga ranah tersebut agar dapat menggambarkan keberhasilan siswa dalam belajar secara utuh. Namun, hal ini tidak sejalan dengan proses penilaian yang terjadi dilapangan. Berdasarkan hasil penelitian yang dilakukan oleh peneliti di Kabupaten Klaten menunjukkan bahwa dari 30 responden dari guru yang diberikan kuesioner menunjukan bahwa $83,3 \%$ guru tidak memiliki instrumen penilaian afektif. Hal tidak sejalan dengan pemahaman guru tentang pentingnya penilaian afektif yaitu sebesar 96\%. Sedangkan pada pelaksanaan penilaian ditemukan sebesar 93,3\% guru tidak melakukan penilaian afektif. Peneliti menindaklanjuti dengan wawancara. Hasil wawancara menunjukkan bahwa ketidaktersedianya instrumen afektif dikarenakan guru mengalami kesulitan dalam 
membuat instrumen penilaian afektif. Kesulitan tersebut disebabkan minimnya contoh penilaian afektif. Wawancara juga dilakukan terkait kendala waktu, sejauh ini kendala yang dialami guru selain kesulitan membuat instrumen yaitu waktu. Guru tidak memiliki cukup waktu untuk membuat instrumen penilaian afektif sehingga guru hanya observasi terhadap sikap yang ditunjukkan siswa pada saat proses pembelajaran maupun pada saat diluar pembelajaran namun masih dalam lingkup sekolah. Bersasarkan Kementerian Pendidikan dan Kebudayaan melalui Direktorat Pembinaan Pendidikan Dasar (2016, p. 6) pada buku Panduan Teknis Pembelajaran dan Penilaian di Sekolah Dasar menjelaskan bahwa dalam melakukan penilaian afektif yang berupa sikap perlu dilakukan konfirmasi sehingga tidak hanya dilakukan dengan observasi. Kurikulum yang diterapkan pemerintah yaitu Kurikulum 2013 mewajibkan guru untuk melakukan penilaian afektif. Penilaian afektif pada Kurikulum 2013 terdapat pada sikap sosial siswa yaitu sikap disiplin, jujur, peduli, percaya diri, santun dan tanggung jawab. Hal tersebut penting dilakukan terkait informasi yang didapatkan untuk menilai afektif siswa berdasarkan observasi terdapat unsur subjektivitas yang dilakukan guru sehingga menghasilkan informasi yang bias dalam penilaian afektif siswa.

Mardapi (2012, p. 15) menjelaskan bahwa instrumen yang dapat digunakan untuk menilai kemampuan afektif adalah bentuk kuesioner dengan disajikan kasus yang selanjutnya siswa diminta untuk memberi respon. Kuesioner yang baik tentu dalam pembuatanya telah melalui prosedur. Terkait hal itu McCoach, Gable, \& Madura (2013, p. 26) menjelaskan bahwa:

"In selecting an affective characteristic for measurement, instrumen developers should carefully consider the theory underlying the construct. Only with a clearconceptual understanding can one proceed to create valid operational definitions (i.e., statements/items) for each affective characteristic."

Definisi tersebut dapat diartikan bahwa dalam memilih karakteristik pada pengembangan instrumen ranah afektif perlu berhati-hati dalam mempertimbangkan pemilihan teori secara konstruk. Dengan pemahaman yang baik dapat menghasilkan definisi operasional yang valid untuk masingmasing karakter pada ranah afektif. Hal ini menunjukkan bahwa dalam melakukan penilaian afektif tidak boleh sembarangan dalam membuat definisi operasional yang kemudian dikembangkan menjadi indikatorindikator sikap yang akan dinilai. Guru tentu perlu memahami hal ini sebagai upaya membantu mengenali sikap yang tercermin dari diri siswa. Selain itu, pada penyusunan butir-butir perlu dilakukan pengujian validitas dan mengestimasi reliabilitas. Validitas dilakukan untuk memastikan layak digunakan untuk mengukur apa yang seharusnya diukur, dan estimasi reliabilitas dimaksudkan instrumen tersebut memiliki keajegan atau konsisten dalam mengukur kemampuan afektif siswa, dalam hal ini adalah sikap siswa. Hasil penelitian yang dilakukan peneliti menunjukkan bahwa tidak ada guru yang melakukan uji validitas dan reliabilitas pada instrumen penilaian afektif siswa. Berdasarkan hal tersebut maka dapat dikatakan bahwa instrumen yang dibuat guru tersebut tidak layak untuk megukur afektif siswa. Instrumen yang tidak layak untuk mengukur afektif siswa menyebabkan tidak tergambarkan kemampuan siswa secara detail. Berdasarkan hal tersebut maka diperlukan instrumen yang layak untuk mengukur afektif siswa berupa sikap sosial siswa yaitu sikap disiplin, jujur, peduli, percaya diri, santun dan tanggung jawab secara detail dengan klasifikasi tingkatan afektif Krathwohl, Bloom \& Masia. Tingkatan tersubut adalah (1) menerima yaitu Kesadaran, kemauan untuk menerima, perhatian terseleksi. Pada tahap ini pembelajar peka terhadap keberadaan fenomena atau rangsangan, (2) merespon yaitu Berpartisipasi aktif sebagai bagian dari pembelajar. Menyimak dan bereaksi terhadap suatu fenomena tertentu. Pada tahap ini pembelajar cukup termotivasi untuk berperan serta dan menghadapi rangsangan yang datang berupa gagasan, benda atau sistem nilai, (3) menilai yaitu terdiri atas menerima nilai, memilih nilai, dan komitmen. Pada tahap ini pembelajar mema- 
hami bahwa benda-benda, gejala atau suatu perilaku mempunyai nilai. (4) mengorganisasi yaitu adanya prioritas untuk membandingkan perbedaan nilai, dan menciptakan suatu sistem nilai yang unik dan (5) karakterisasi yaitu memiliki sistem nilai yang mengontrol perilakunya, ajeg dapat diramalkan, dan yang paling penting merupakan karakteristik dari pembelajar sehingga tataran ini disebut pula karakterisasi nilai serta gambaran afektif siswa berdasarkan acuan Kurikulum 2013.

\section{Metode Penelitian}

Penelitian ini merupakan jenis penelitian pengembangan. Model yang digunakan pada penelitian ini mengacu pada model dari Thiagarajan, et al. Model pengembangan Thiagarajan, Semmel, \& Semmel (1974) atau sering disebut dengan Four-D Model ini terdiri dari 4 tahapan pengembangan yaitu define (pendefinisian), design (perancangan), develop (pengembanagan) dan dissemination (penyebaran). Model pengembangan tersebut disajikan pada Gambar 1.

Intrumen yang dikembangkan menggunakan model Thiagarajan adalah instrumen penilaian afektif untuk siswa sekolah dasar khususnya kelas IV. Jenis instrumen yang dikembangkan adalah penilaian diri. Siswa melakukan penialain diri terhadap sikap disiplin, jujur, peduli, percaya diri, santun, dan tanggung jawab. Pengembangan instrumen pada tahap awal dilakukan dengan kontrak teori dari keenam sikap tersebut. Konstrak teori yang didapatkan pada setiap sikap dikembangkan menjadi indikator yang dapat disusun oleh peneliti bersama guru dalam FGD.

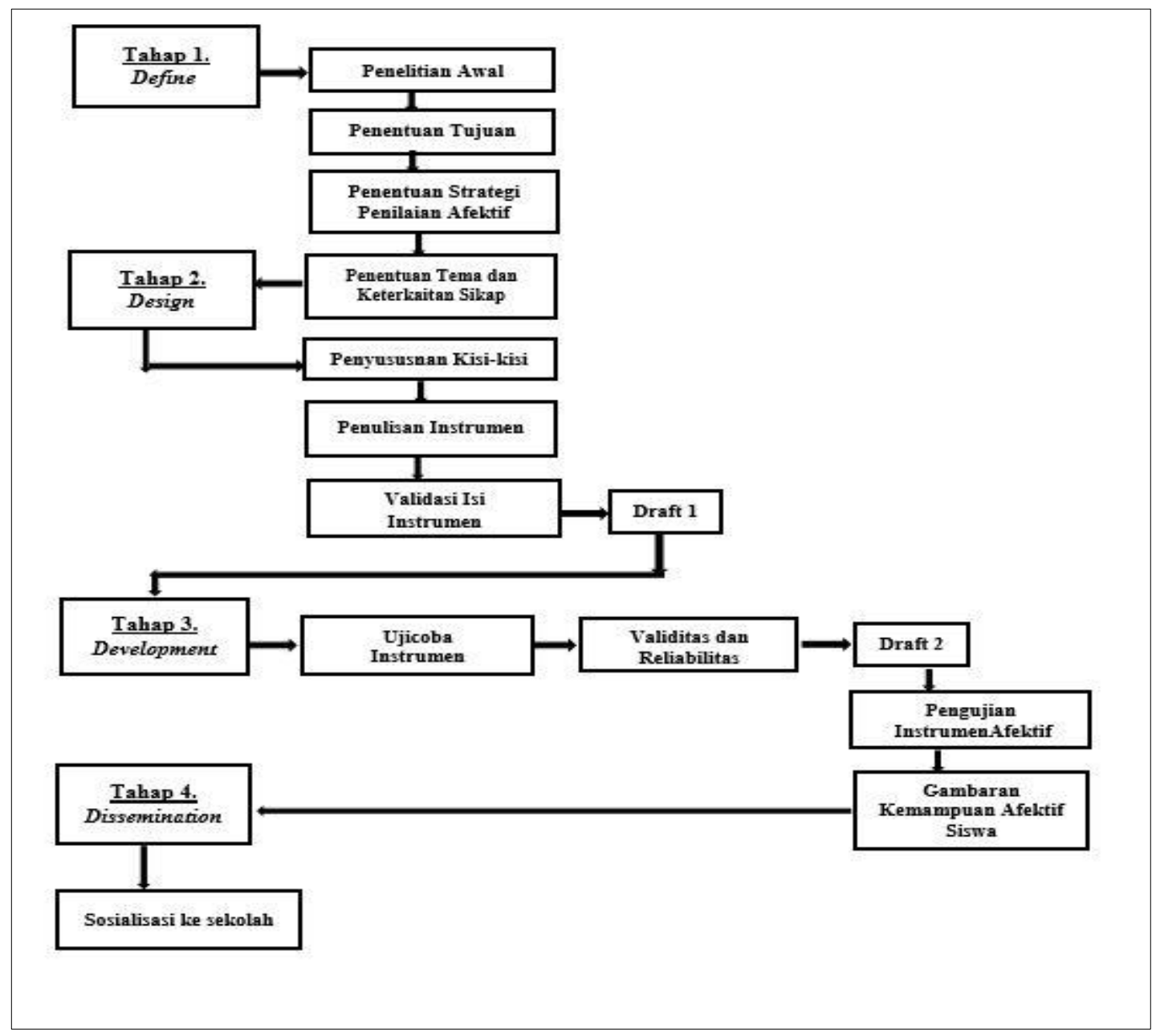

Gambar 1. Desain Pengembangan Penilaian Afektif 
Hasil FGD tersebut lalu diuji validitasnya dan diestimasi reliabilitasnya. Validitas diuji secara isi dan kontrak. Validitas isi diuji oleh ahli dan dianalisis menggunakan rumus Aiken's. Retnawari (2016, p.19) mengatakan bahwa besarnya koefisien validitas yang dapat diterima dan dianggap sudah layak adalah $\geq 0,40$. Validitas konstrak dilakukan dengan uji analisis faktor eksploratori dan konfirmatori. Wagiran (2015, p. 300) mengatakan bahwa analisis faktor eksploratori dilakukan untuk memastikan apakah butir-butir tertentu mendukung faktornya dan faktor-faktor tersebut mendukung variabelnya.

Kriteria analisis faktor eksploratori menurut Wagiran (2015, p. 303) adalah sebagai berikut:

Tabel 1. Kriteria analisis faktor eksploratori

\begin{tabular}{lc}
\hline Kriteria & Nilai \\
\hline Keyser Mayer Oikin (KMO) & $>0,5$ \\
Barlett's Test of Sphericity & $>0,05$ \\
Anti image correlation & MSA $>0,5$ \\
Nilai Eigen & $>1$ \\
Rotasi faktor & $>0,4$ \\
\hline
\end{tabular}

Berdasarkan hasil analisis faktor eksploratori maka di dapatkan instrumen yang valid. Instrumen yang valid kemudian dilakukan uji lanjut yaitu analisis faktor konfirmatori. Hendryadi \& Suryani (2014, p. 63) menyatakan bahwa analisis tersebut memiliki tujuan untuk melihat apakah model yang diusulkan memiliki kecocokan yang baik (good fit) atau belum. Parameter kecocokan analisis faktor konfirmatori menurut Hendryadi \& Suryani (2014, pp. 18-19) disajikan pada Tabel 2.

Tabel 2. Parameter Kecocokan Model Analisis Faktor Konfirmatori

\begin{tabular}{lc}
\hline Kriteria & Nilai \\
\hline Chi Kuadrat & P value $>0,05$ \\
Root Means Square Error of Approximation & RSMEA $\leq 0,08$ \\
(RSMEA) & \\
Goodness Of Fit Indeks ( GFI) & GFI $\geq 0,09$ \\
Standardized Root Mean Square Residual & SRMR $\leq 0,05$ \\
( SRMR) & \\
Adjusted Goodnews Fit Of Indeks ( AGFI) & AGFI $\geq 0,90$ \\
Comparative Fit Indeks (CFI) & CFI $\geq 0,90$ \\
Incremental For Index ( RFI) & RFI $\geq 0,90$ \\
\hline
\end{tabular}

Pada tahap selanjutnya, instrumen yang telah dinyatakan valid diestimasi reliabilitasnya. Kriteria untuk menentukan reliabilitas instrumen didasarkan atas koefisien Alpha > 0,5 (Wagiran, 2015). Reliabilitas konstrak instrumen dapat didapatkan dari hasil perhitungan analisis faktor konfirmatori menggunakan formula Construct Reliaility (CR) dan Variance Extract (VE). Hendryadi \& Suryani 2014 , p. 17) menyebutkan bahwa nilai reliabilitas CR disarankan lebih dari 0,7 sedangkan nilai VE disarankan lebih besar dari 0,5. Formula untuk menghitung reliabilitas konstrak menurut Hendryadi \& Suryani (2014, pp. 17-18) adalah sebagai berikut:

Contruct Relialit

$=\frac{\left(\sum \text { Standarized loading }\right)^{2}}{\left(\sum \text { Standarized loading }\right)^{2}+\left(\sum \text { SMeasurement Error }\right)}$

Variance Extract $\frac{\sum \text { Standarized loading }^{2}}{\sum \text { Standarized loading }^{2}+\left(\sum \text { SMeasurement Error }^{2}\right)}$
Uji coba dilakukan pada siswa Sekolah Dasar Kelas IV di Kabupaten Klaten pada semester 2 tahun ajaran 2016/2017. Uji coba dilakukan pada sekolah dasar yang menggunakan Kurikulum 2013 di Kabupaten Klaten. Daftar SD tersebut disajikan pada Tabel 3.

Subjek penelitian dalam penelitian ini adalah siswa kelas IV sekolah dasar di $\mathrm{Ka}$ bupaten Klaten pada semester 2 yang disajikan pada Tabel 4.

Penentuan subjek coba pada penelitian ini menggunakan non-probalility sampling dengan teknik purposive sampling. Wagiran (2015, p. 210) menjelaskan bahwa pada teknik purposive sampling dipilih berdasarkan tujuan dan maksud tertentu. Tujuan dipilihnya subjek coba pada penelitian ini merupakan sekolah yang terpilih yaitu sekolah yang telah menerapkan Kurikulum 2013 secara keseluruhan. Karateristik sekolah yang sesuai dengan penelitian ini terdapat pada 13 SD dan 6 SD sebagai subjek ujicoba. Sekolah-sekolah tersebut oleh Dinas Pendidikan Kabupaten Klaten ditunjuk sebagai Sekolah Dasar percontohan penerapan Kurikulum 2013 dalam implementasi kurikulum guru yang akan diajak pada proses FGD tidak mengalami 
kesulitan. Berdasarkan hal tersebut semua siswa kelas IV sekolah tersebut dilibatkan sebagai subjek coba.

Tabel 3. Subjek Uji Coba

\begin{tabular}{lc}
\hline Nama Sekolah & Jumlah \\
\hline SD N 1 Brajan & 30 \\
SD N 2 Brajan & 30 \\
SD N 3 Kemudo & 28 \\
SD N 1 Kebondalem Lor & 52 \\
SD N 2 Cucukan & 25 \\
SD N 1 Joho & 31 \\
\hline Jumlah & 196 \\
\hline
\end{tabular}

Tabel 4. Subjek Penelitian

\begin{tabular}{lc}
\hline Nama Sekolah & Jumlah \\
\hline SD Muh. Tonggalan & 89 \\
SD N 1 Tegalyoso & 28 \\
SD N 1 Prambanan & 39 \\
SD N2 Prambanan & 39 \\
SD N 2 Taskombang & 22 \\
SD N Kendalsari & 49 \\
SD N 1 Bonyokan & 54 \\
SD N Gatak & 51 \\
SD N Mlese & 13 \\
SD N 1 Tegalgondo & 28 \\
SD N Kradenan & 54 \\
SD N 2 Cawas & 38 \\
SD N 1 Paseban & 41 \\
\hline Jumlah & 548 \\
\hline
\end{tabular}

\section{Hasil Penelitian dan Pembahasan}

Validitas dan Reliabilitas Instrumen

Validitas terdiri dari validitas isi dan konstrak sedangkan reliabilitas diestimasi dengan Alpha Cronbach dan secara konstrak. Hasil dari validitas isi menunjukkan bahwa indeks Aiken sebesar 0,85 sehingga dapat dikatakan bahwa Instrumen tersebut valid secara isi. Validitas Kontrak dibuktikan dengan analisis faktor ekploratori dan konfirmatori. Hasil dari analisis faktor eksploratori disajikan pada Tabel 5.

Berdasarkan hasil yang didapatkan berdasarkan analisis faktor eksploratori dan analisis faktor konfirmatori maka dapat disimpulkan bahwa 18 butir tersebut valid. Butir yang telah didapatkan tersebut dapat digambarkan pada hasil analisis faktor konfirmatori. Model yang sudah memiliki kesesuain yang baik tersebut dapat dilihat pada standardized solution pada Gambar 2.

Berdasarkan gambar model yang dilihat dari standardization solution menunjukkan bahwa p-value 0,39 dan RSMEA yang mendekati 0 yaitu 0,012 maka dapar dikatakan bahwa model faktor yang digunakan baik atau terdapat kecocokan model. Selain pada standardized solution, dapat juga dilihat melalui $t$ value dengan ditunjukkan oleh Gambar 3.

Tabel 5. Hasil Analisis Faktor Eksploratori

\begin{tabular}{ll}
\hline \multicolumn{1}{c}{$\begin{array}{c}\text { Analisis Faktor } \\
\text { Eksploratori }\end{array}$} & \multicolumn{1}{c}{ Hasil } \\
\hline $\begin{array}{l}\text { Kaiser-Meyer-Olkin } \\
\text { (KMO) sampling } \\
\text { adequacy }\end{array}$ & \multicolumn{1}{c}{0,726} \\
\hline $\begin{array}{l}\text { Bartlett's Test of } \\
\text { Sphericity }\end{array}$ & \multicolumn{1}{c}{0,000} \\
\hline Nilai MSA & 0,$779 ; 0,869 ; 0,727 ; 0,817 ;$ \\
& 0,$734 ; 0,656 ; 0,869 ; 0,754 ;$ \\
& 0,$688 ; 0,783 ; 0,608 ; 0,694 ;$ \\
& 0,$655 ; 0,668 ; 0,712 ; 0,612 ;$ \\
& $0,663$. \\
\hline Nilai Eigen & 4,$232 ; 3,321 ; 2,494 ; 2,467 ;$ \\
& 2,$088 ; 1,177$ \\
\hline Rotated Componen & Disiplin: \\
& 0,$98 ; 0,97 ; 0,98$ \\
& Jujur: \\
& 0,$98 ; 0,99 ; 0,99$ \\
& Peduli: \\
& 0,$97 ; 0,97 ; 0,97$ \\
& Percaya Diri: \\
& 0,$94 ; 0,91 ; 0,97$ \\
& Santun: \\
& 0,$72 ; 0,82 ; 0,86$ \\
& Tanggung Jawab: \\
& 0,$67 ; 0,85 ; 0,70$ \\
&
\end{tabular}

Tabel 6. Hasil Analisis Faktor Konfirmatori

\begin{tabular}{lc}
\hline Analisis Faktor Konfirmatori & Hasil \\
\hline Chi-Kuadrat & 0.039 \\
RSMEA & 0.012 \\
GFI & 0,93 \\
SRMR & 0,03 \\
AGFI & 0,90 \\
CFI & 1,00 \\
RFI & 1,00 \\
\hline
\end{tabular}

Pengembangan Instrumen Penilaian Afektif Siswa ... - 237 Anggarwati Riscaputantri, Sri Wening 


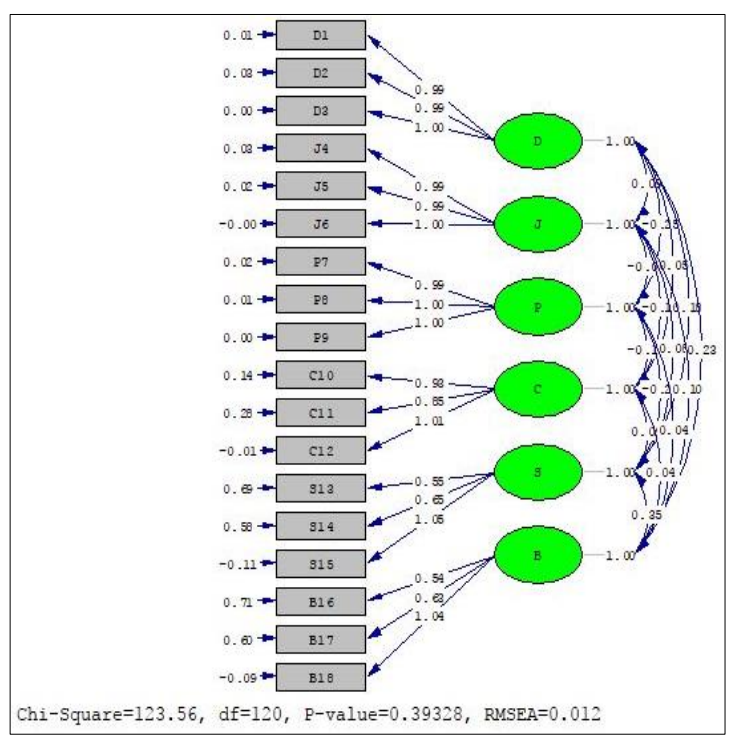

Gambar 2. Basic Model Standarization Solution

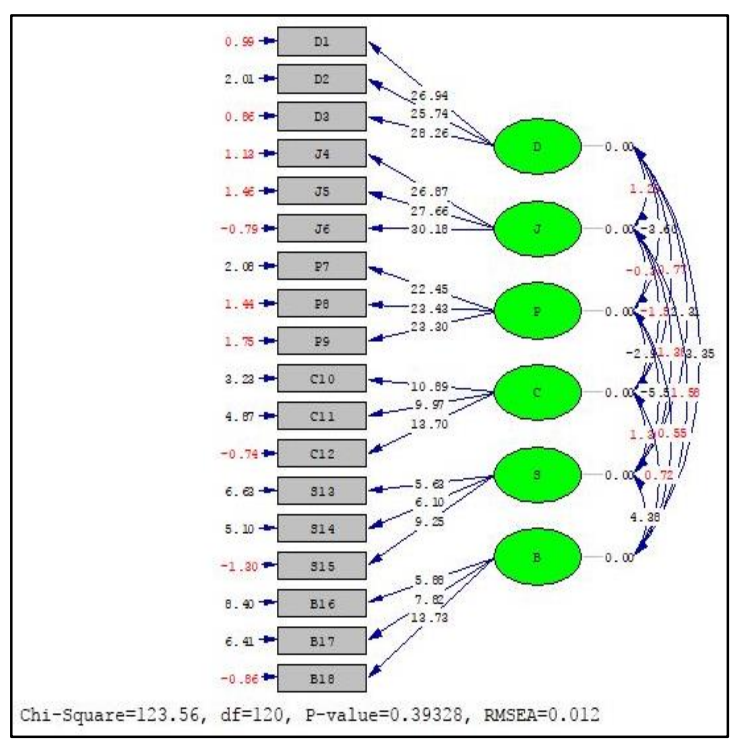

Gambar 3. Basic Model T-Value

Tabel 7. Hasil Reliabilitas Berdasarkan Alpha Cronbach

\begin{tabular}{cc}
\hline Reliabilitas Alpha Cronbach & Ket. \\
\hline 0,694 & Reliabel \\
\hline
\end{tabular}

Tabel 8. Hasil Reliabilitas Konstrak Berdasarkan Alpha Cronbach

\begin{tabular}{ccc}
\hline \multicolumn{3}{c}{ Reliabilitas Konstrak } \\
\hline CR & VE & Ket \\
\hline 0,995 & 0,995 & Reliabel \\
0,994 & 0,995 & Reliabel \\
0,996 & 0,997 & Reliabel \\
0,949 & 0,951 & Reliabel \\
0,994 & 0,811 & Reliabel \\
0,993 & 0,798 & Reliabel \\
\hline
\end{tabular}

Berdasarkan hasil validitas dan reliabilitas diperoleh diperoleh 18 butir dengan indikator penilaian atau kisi-kisi sebagai berikut.

Tabel 9. Kisi-Kisi Penilaian Afektif Siswa

\begin{tabular}{|c|c|c|}
\hline Sikap Siswa & Indikator & $\begin{array}{l}\text { No. } \\
\text { Butir }\end{array}$ \\
\hline \multirow[t]{2}{*}{ Disiplin } & $\begin{array}{l}\text { Tepat waktu dalam } \\
\text { melakukan atau } \\
\text { mengerjakan sesuatu }\end{array}$ & 1,2 \\
\hline & $\begin{array}{l}\text { Tertib dalam } \\
\text { menjalankan peraturan }\end{array}$ & 3 \\
\hline \multirow[t]{2}{*}{ Jujur } & $\begin{array}{l}\text { Menyampaikan } \\
\text { sesuatu dengn keadaan } \\
\text { yang sebenarnya }\end{array}$ & 4,5 \\
\hline & $\begin{array}{l}\text { Mengaku kekurangan } \\
\text { ataupun keterbatasan }\end{array}$ & 6 \\
\hline \multirow[t]{2}{*}{ Peduli } & $\begin{array}{l}\text { Berpartisipasi dalam } \\
\text { kegiatan }\end{array}$ & 7,8 \\
\hline & $\begin{array}{l}\text { Menunjukkan } \\
\text { perhatian kepada } \\
\text { orang lain ataupun } \\
\text { lingkungan sekitar }\end{array}$ & 9 \\
\hline \multirow{3}{*}{$\begin{array}{l}\text { Percaya } \\
\text { Diri }\end{array}$} & Bergantung pada & 10 \\
\hline & kemampuan sendiri & \\
\hline & $\begin{array}{l}\text { Berani } \\
\text { mengungkapkan } \\
\text { sesuatu }\end{array}$ & 11,12 \\
\hline \multirow[t]{2}{*}{ Santun } & $\begin{array}{l}\text { Menghormati orang } \\
\text { lain dengan cara } \\
\text { berbicara atau bertutur } \\
\text { kata halus }\end{array}$ & 13,14 \\
\hline & $\begin{array}{l}\text { Dapat mengendalikan } \\
\text { perilaku atau } \\
\text { perbuatan walaupun } \\
\text { mendapatkan kesulitan } \\
\text { atau masalah }\end{array}$ & 15 \\
\hline \multirow[t]{2}{*}{$\begin{array}{l}\text { Tanggung } \\
\text { jawab }\end{array}$} & $\begin{array}{l}\text { Melaksanakan tugas } \\
\text { dengan baik }\end{array}$ & 16 \\
\hline & $\begin{array}{l}\text { Menerima resiko dari } \\
\text { tindakan yang } \\
\text { dilakukan }\end{array}$ & 17,18 \\
\hline
\end{tabular}

Gambaran Sikap Afektif Siswa

Gambaran afektif dalam penelitian ini disajikan dalam: (1) tingkatan afektif Krathwohl, Bloom \& Masia; (2) acuan Kurikulum 2013. Gambaran afektif siswa secara keseluruhan berdasarkan tingkatan afektif Krathwohl, Bloom dan Masia disajikan dalam Tabel 10. 
Tabel 10. Afektif Siswa secara Keseluruhan

\begin{tabular}{lccc}
\hline \multicolumn{1}{c}{ Skor } & Kategori & $\mathrm{f}$ & $\%$ \\
\hline$>75,6$ & Karakterisasi & 235 & 42,9 \\
$>61,2-75,6$ & Mengorganisasi & 279 & 50,9 \\
$>56,8-61,2$ & Menilai & 34 & 6,2 \\
$>32,4-46,8$ & Merespon & 0 & 0 \\
$8-32,4$ & Menerima & 0 & 0 \\
\hline Jumlah & & 548 & 100 \\
\hline
\end{tabular}

Tabel 10 menunjukkan bahwa kemampuan siswa kelas IV Kabupaten Klaten diliat dari kategori berdasarkan tingkatan afektif Krathwohl, Bloom \& Masia dari 548 siswa terdapat 235 siswa yang mencapai karakterisasi dengan persentase sebesar 42,9\%, 279 siswa mencapai tingkatan mengorganisasi dengan persentase $50,9 \%, 34$ siswa mencapai tingkatan menilai dengan persentase $6,2 \%$ sedangkan pada tingkatan merespon dan menerima persentase $0 \%$ atau dapat dikatakan tidak ada siswa yang mencapai pada kedua tingkatan tersebut. Kemampuan afektif siswa berdasarkan tingkatan Krathwohl, Bloom \& Masia ditunjukkan pada Gambar 4.

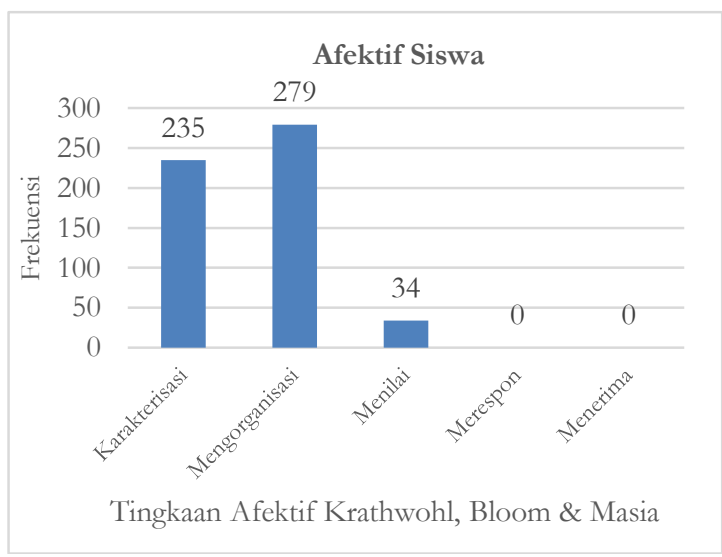

Gambar 4. Afektif Siswa secara

Keseluruhan Berdasarkan TIngkatan Afektif Krathwohl, Bloom \& Masia

Gambaran pada setiap sikap berdasarkan tingkatan afektif Krathwohl, Bloom dan Masia adalah sebagai berikut:

Disiplin

Gambaran sikap disiplin siswa berdasarkan tingkatan afektif Krathwohl, Bloom dan Masia digambarkan pada Tabel 11.
Tabel 11. Sikap Disiplin

\begin{tabular}{lccc}
\hline \multicolumn{1}{c}{ Skor } & Kategori & $\mathrm{f}$ & $\%$ \\
\hline$>12,6$ & Karakterisasi & 155 & 28 \\
$>10,2-12,6$ & Mengorganisasi & 274 & 50 \\
$>7,8-10,2$ & Menilai & 110 & 20 \\
$>5,4-7,8$ & Merespon & 9 & 2 \\
3- 5,4 & Menerima & 0 & 0 \\
\hline Jumlah & & 548 & 100 \\
\hline
\end{tabular}

Jijur

Gambaran sikap jujur siswa berdasarkan tingkatan afektif Krathwohl, Bloom \& Masia digambarkan pada Tabel 12.

Tabel 12. Sikap Jujur

\begin{tabular}{lccc}
\hline \multicolumn{1}{c}{ Skor } & Kategori & $\mathrm{f}$ & $\%$ \\
\hline$>12,6$ & Karakterisasi & 171 & 31 \\
$>10,2-12,6$ & Mengorganisasi & 171 & 31 \\
$>7,8-10,2$ & Menilai & 173 & 32 \\
$>5,4-7,8$ & Merespon & 28 & 5 \\
3- 5,4 & Menerima & 5 & 1 \\
\hline Jumlah & & 548 & 100 \\
\hline
\end{tabular}

Peduli

Gambaran sikap peduli siswa berdasarkan tingkatan afektif Krathwohl, Bloom dan Masia digabarkan pada Tabel 13.

Tabel 13. Sikap Peduli

\begin{tabular}{lccc}
\hline \multicolumn{1}{c}{ Skor } & Kategori & $\mathrm{f}$ & $\%$ \\
\hline$>12,6$ & Karakterisasi & 326 & 59,5 \\
$>10,2-12,6$ & Mengorganisasi & 121 & 22,1 \\
$>7,8-10,2$ & Menilai & 61 & 14,8 \\
$>5,4-7,8$ & Merespon & 18 & 3,3 \\
3- 5,4 & Menerima & 2 & 0,4 \\
\hline Jumlah & & 548 & 100 \\
\hline
\end{tabular}

Percaya Diri

Gambaran sikap percaya diri siswa berdasarkan tingkatan afektif Krathwohl, Bloom dan Masia digabarkan pada Tabel 14.

Tabel 14. Sikap Percaya Diri

\begin{tabular}{lccc}
\hline \multicolumn{1}{c}{ Skor } & Kategori & $\mathrm{f}$ & $\%$ \\
\hline$>12,6$ & Karakterisasi & 289 & 52,7 \\
$>10,2-12,6$ & Mengorganisasi & 199 & 36,3 \\
$>7,8-10,2$ & Menilai & 57 & 10,4 \\
$>5,4-7,8$ & Merespon & 1 & 0,2 \\
$3-5,4$ & Menerima & 2 & 0,4 \\
\hline Jumlah & 548 & 100 \\
\hline \multicolumn{3}{c}{ Pengembangan Instrumen Penilaian Afektif Siswa ... } & -239 \\
Anggarwati Riscaputantri, Sri Wening &
\end{tabular}




\section{Santun}

Gambaran sikap santun siswa berdasarkan tingkatan afektif Krathwohl, Bloom dan Masia digabarkan pada Tabel 15.

Tabel 15. Sikap Peduli

\begin{tabular}{lccc}
\hline \multicolumn{1}{c}{ Skor } & Kategori & $\mathrm{f}$ & $\%$ \\
\hline$>12,6$ & Karakterisasi & 358 & 65,3 \\
$>10,2-12,6$ & Mengorganisasi & 119 & 21,7 \\
$>7,8-10,2$ & Menilai & 64 & 11,7 \\
$>5,4-7,8$ & Merespon & 7 & 1,3 \\
$3-5,4$ & Menerima & 0 & 0 \\
\hline Jumlah & & 548 & 100 \\
\hline
\end{tabular}

Tanggung Jawab

Gambaran sikap tanggung jawab siswa berdasarkan tingkatan afektif Krathwohl, Bloom dan Masia digabarkan pada Tabel 16.

Tabel 16. Sikap Peduli

\begin{tabular}{lccc}
\hline \multicolumn{1}{c}{ Skor } & Kategori & $\mathrm{f}$ & $\%$ \\
\hline$>12,6$ & Karakterisasi & 322 & 58,8 \\
$>10,2-12,6$ & Mengorganisasi & 129 & 23,5 \\
$>7,8-10,2$ & Menilai & 75 & 13,7 \\
$>5,4-7,8$ & Merespon & 22 & 4,0 \\
3- 5,4 & Menerima & 0 & 0 \\
Jumlah & & 548 & 100 \\
\hline
\end{tabular}

Gambaran afektif siswa secara keseluruhan berdasarkan acuan Kurikulum 2013 disajikan dalam Tabel 17.

Tabel 17. Afektif Siswa Secara Keseluruhan

\begin{tabular}{lccc}
\hline \multicolumn{1}{c}{ Skor } & Kategori & f & $\%$ \\
\hline$>72$ & Baik Sekali & 338 & 62 \\
$>54-72$ & Baik & 206 & 38 \\
$>36-54$ & Cukup & 4 & 1 \\
$18-36$ & Perlu Bimbingan & 0 & 0 \\
\hline Jumlah & & 548 & 100 \\
\hline
\end{tabular}

Berdasarkan Tabel 17 menunjukkan bahwa kemampuan afektif siswa kelas IV Kabupaten Klaten dilihat dari kategori Kurikulum 2013 terdapat 338 siswa yang masuk dalam kategori Baik Sekali dengan persentasenya $62 \%$. Pada kategori Baik terdapat 206 siswa dengan persentase 38\% siswa sedangkan kategori cukup menunjukkan terdapat 4 siswa yang masuk dalam kategori ter- sebut dengan persentase $1 \%$, pada kategori perlu bimbingan sebesar $0 \%$ yang dapat digambarkan pada Gambar 5.

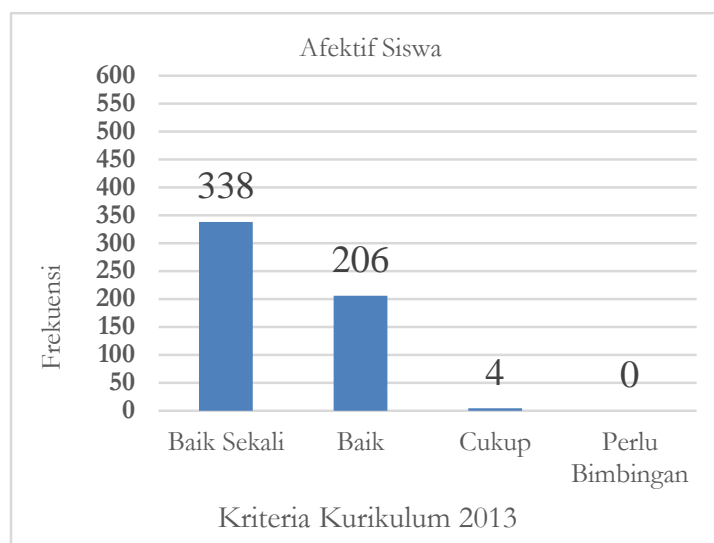

Gambar 5. Afektif Siswa secara Keseluruhan Berdasarkan Acuan Kurikulum 2013

Gambaran pada setiap sikap berdasarkan acuan Kurikulum 2013 adalah sebagai berikut:

\section{Disiplin}

Gambaran afektif siswa pada sikap disiplin secara keseluruhan berdasarkan acuan Kurikulum 2013 disajikan dalam Tabel 18.

Tabel 18. Sikap Disiplin

\begin{tabular}{lccc}
\hline \multicolumn{1}{c}{ Skor } & Kategori & f & $\%$ \\
\hline$>12$ & Baik Sekali & 155 & 28,3 \\
$>9-12$ & Baik & 345 & 63 \\
$>6-9$ & Cukup & 46 & 8,3 \\
$18-36$ & Perlu Bimbingan & 2 & 0,4 \\
\hline Jumlah & & 548 & 100 \\
\hline
\end{tabular}

Jijur

Gambaran afektif siswa pada sikap jujur secara keseluruhan berdasarkan acuan Kurikulum 2013 disajikan dalam Tabel 19.

Tabel 19. Sikap Jujur

\begin{tabular}{lccc}
\hline \multicolumn{1}{c}{ Skor } & Kategori & $\mathrm{f}$ & $\%$ \\
\hline$>12$ & Baik Sekali & 171 & 31,2 \\
$>9-12$ & Baik & 229 & 41,8 \\
$>6-9$ & Cukup & 134 & 24,5 \\
$18-36$ & Perlu Bimbingan & 14 & 2,6 \\
\hline Jumlah & & 548 & 100 \\
\hline
\end{tabular}




\section{Peduli}

Gambaran afektif siswa pada sikap peduli secara keseluruhan berdasarkan acuan Kurikulum 2013 disajikan dalam Tabel 20.

Tabel 20. Sikap Peduli

\begin{tabular}{lccc}
\hline \multicolumn{1}{c}{ Skor } & Kategori & $\mathrm{f}$ & $\%$ \\
\hline$>12$ & Baik Sekali & 326 & 59,5 \\
$>9-12$ & Baik & 153 & 27,9 \\
$>6-9$ & Cukup & 59 & 10,8 \\
$18-36$ & Perlu Bimbingan & 10 & 1,8 \\
\hline Jumlah & & 548 & 100 \\
\hline
\end{tabular}

Percaya Diri

Gambaran afektif siswa pada sikap per-caya diri secara keseluruhan berdasarkan acuan Kurikulum 2013 disajikan dalam Tabel 21.

Tabel 21. Percaya Diri

\begin{tabular}{lccc}
\hline \multicolumn{1}{c}{ Skor } & Kategori & \multicolumn{1}{c}{ f } & $\%$ \\
\hline$>12$ & Baik Sekali & 289 & 52,7 \\
$>9-12$ & Baik & 220 & 40,1 \\
$>6-9$ & Cukup & 37 & 6,8 \\
$18-36$ & Perlu Bimbingan & 2 & 0,4 \\
\hline Jumlah & & 548 & 100 \\
\hline
\end{tabular}

Santun

Gambaran afektif siswa pada sikap santun secara keseluruhan berdasarkan acuan Kurikulum 2013 disajikan dalam Tabel 22.

Tabel 22. Sikap Santun

\begin{tabular}{lccc}
\hline \multicolumn{1}{c}{ Skor } & Kategori & f & $\%$ \\
\hline$>12$ & Baik Sekali & 358 & 65,3 \\
$>9-12$ & Baik & 145 & 26,5 \\
$>6-9$ & Cukup & 42 & 7,7 \\
$18-36$ & Perlu Bimbingan & 3 & 0,5 \\
\hline Jumlah & & 548 & 100 \\
\hline
\end{tabular}

Tanggung Jawab

Tabel 23. Sikap Disiplin

\begin{tabular}{lccc}
\hline \multicolumn{1}{c}{ Skor } & Kategori & $\mathrm{f}$ & $\%$ \\
\hline$>12$ & Baik Sekali & 323 & 58,9 \\
$>9-12$ & Baik & 170 & 31 \\
$>6-9$ & Cukup & 48 & 8,8 \\
$18-36$ & Perlu Bimbingan & 7 & 1,3 \\
\hline Jumlah & & 548 & 100 \\
\hline
\end{tabular}

Gambaran afektif siswa pada sikap tanggung jwab secara keseluruhan berdasarkan acuan Kurikulum 2013 disajikan dalam Tabel 23.

\section{Simpulan}

Berdasarkan hasil penelitian maka dapat disimpulkan bahwa (1) instrumen penilaian untuk mengukur afektif siswa kelas IV berjumlah 18 butir telah memenuhi syarat yaitu validitas dan reliabilitas; (2) Gambaran afektif siswa adalah (a) berdasarkan tingkatan afektif Krathwohl, Bloom \& Masia pada tingkatan karakterisasi sebesar 42,9\%, mengorganisasi sebesar $50,9 \%$, menilai $6,2 \%$ sedangkan tahapan merepon dan menerima sebesar $0 \%$, (b) berdasarkan acuan Kurikulum 2013 pada kategori baik sekali sebesar $62 \%$, kategori baik 38\% dan kategori cukup 1\%, kategori butuh bimbingan sebesar $0 \%$.

Saran yang dapat diberikan dalam pemanafaatan produk adalah sebagai berikut: (1) pada proses pembelajaran sebaiknya guru merancang pembelajaran yang mengasah afektif siswa; (2) instrumen ini dapat digunakan untuk mengeeahui sejauhmana tingkatan yang telah dicapai siswa berdasarkan tingkatan afektif Krathwohl, Bloom \& Masia yaitu karakerisasi mencapai, mengorganisasi, menilai, merespon dan menerima; (3) bagi guruguru yang akan mengetahui kemampuan afektif siswa berdasarkan tigkatan Krathwohl, Bloom \& Masia dapat menggunakan instrumen ini dikarenakan telah layak, (4) bagi guru-guru yang ingin mengembangkan instrumen penilaian afektif siswa pada jenjang yang lain diharapkan dapat mengikuti langkah-langkah yang tersedia dalam penelitian ini.

\section{Daftar Pustaka}

Adibatin, A. (2016). Pendidikan karakter bangsa berbasis strategi pembelajaran pakem melalui permainan cincin di jempol tangan (karya inovasi pembelajaran sekolah dasar). Scholaria, 6(1). Retrieved from http://ejournal.uksw.edu/scholaria/ar ticle/download/180/168 
Haryadi, T., \& Aripin, A. (2015). Melatih kecerdasan kognitif, afektif, dan psikomotorik anak sekolah dasar melalui perancangan game simulasi "warungku." Andharupa; Jurnal Desain Komunikasi Visual \& Multimedia, 1(2). Retrieved from https://publikasi.dinus.ac.id/index.ph $\mathrm{p} /$ andharupa/article/view/963

Hendryadi, \& Suryani. (2014). Structural equation modeling dengan lisrel 8.80 pedoman untuk pemula. Yogyakarta: Kaukaba Dipantara.

Kementerian Pendidikan dan Kebudayaan melalui Direktorat Pembinaan Pendidikan Dasar. (2016). Buku panduan penilaian sekolah dasar. Jakarta: Kementrian Pendidikan dan Kebudayaan melalui Direktorat Pembinaan Pendidikan Dasar.

Krathwohl, D. R., Bloom, B. S., \& Masia, B. B. (1973). Taxonomy of educational objectives. London: David McKay Company.

Mardapi, D. (2012). Teknik penyusunan instrumen tes dan non tes. Yogyakarta: Mitra Cendekia.

McCoach, D. B., Gable, R. K., \& Madura, J. P. (2013). Instrument development in the affective domain. New York: Springer New York. https://doi.org/10.1007/978-1-46147135-6

Menteri Pendidikan dan Kebudayaan Republik Indonesia. Peraturan Menteri
Pendidikan dan Kebudayaan Republik Indonesia Nomor 23 Tahun 2015 tentang Penumbuhan Budi Pekerti (2015).

Menteri Pendidikan dan Kebudayaan Republik Indonesia. Peraturan Menteri Pendidikan dan Kebudayaan Republik Indonesia Nomor 23 Tahun 2013 tentang Standar Penilaian (2016).

Samani, H., \& Hariyanto. (2012). Pendidikan karakter. Bandung: PT Remaja Rosdakarya.

Setyawan, H., \& Dimyati, D. (2015). Model permainan aktivitas luar kelas untuk mengembangkan ranah kognitif, afektif, dan psikomotorik siswa SMA. Jurnal Keolabragaan, 3(2). Retrieved from https://journal.uny.ac.id/index.php/jo lahraga/article/view/6230

Thiagarajan, S., Semmel, D. S., \& Semmel, M. I. (1974). Instructional development for training teachers of exceptional children. Bloomington: Indiana University.

Wagiran. (2015). Metodologi penelitian pendidikan. Yogyakarta: Budi Utama.

Wening, S. (2012). Pendidikan karakter bangsa melalui pendidikan nilai. Jurnal Pendidikan Karakter, 1(12). Retrieved from https://journal.uny.ac.id/index.php/jp $\mathrm{ka} /$ article/view/1452 